\title{
REMARKS ON THE METHODOLOGY OF PRIVATE LAW STUDIES: THE USE OF LATIN MAXIMS AS EXEMPLIFIED BY NEMO PLUS IURIS
}

\section{Franciszek Longchamps de Bérier*}

\section{Using Roman rules and maxims}

Honouring the spoken word was deeply embedded in the Roman mentality and played a significant role in the building of relationships among citizens. The Quirites took pride in fides Romana, which distinguished them from the proverbial perfidy of the Carthaginians or fickleness of the Greeks, who considered themselves bound only by the written word, if at all. Keeping one's word, remaining true to one's promises has become part of our legal culture which is rooted in Latin antiquity. This is as valid today as it was then, and is an expression of the constant diligence required when building mutual trust - within the legal order as in other spheres. Indeed, the law as a whole - both that of Rome and of our times - is based on goodwill and a presumption of good intentions on the part of others, since it is a fundamental expectation in interpreting human behaviour. It is words that are first interpreted. We pick our words with great care and, particularly in public discourse, often like to use Latin dicta. We do so not only to make our arguments sound more

* Professor, Jagiellonian University, Krakow.

\section{UNISA $\cong$}


sophisticated, but also to support our theses not merely with elegantly worded, classical maxims, but also with well tested, established concepts based on the experience of people who lived in ancient Rome, a consummately practical society, very well versed in the practice of law. The Roman findings have been tested in a variety of social and economic conditions throughout the centuries of legal history and the various epochs during which the European legal tradition has been formed. Indeed, that tradition has never stopped drawing liberally upon Roman law, and still does so, even today. Latin expressions and phrases invoked in legal parlance find their way into written works, including studies on private law. In research works, Latin expressions, whether sentences, maxims, rules, proverbs, or sayings, seem to play the role of topoi. Sometimes the sentences denote the topoi themselves; at other times, the sentences refer to the topoi as the place and substance of interpretation: as elements or premises used in reasoning, developing an argument, and adding depth to analysis.

In the European legal tradition, it is a matter of pride that the foundations of Europe's laws were laid down by the ancients. The best-known quotation expressing such pride may be found in Montesquieu's Je me trouve fort dans mes maximes lorsque j'ai pour moi les Romains (I am strongly confirmed in my sentiments upon finding the Romans on my side). ${ }^{1}$ The everyday use of Latin legal maxims is a symbolic acknowledgement of the Roman legacy that laid the foundations of our law, especially private law. However, the dicta play a far more important role than that: they are a means of communication and mutual understanding. They express values protected by law, and are a sign of universal acceptance of the concepts they express. ${ }^{2}$ Some Latin phrases and expressions involve common topoi-loci communes, which refer to matters of general concern. They are the points of departure providing the grounds for all persuasive discourse - for instance audiatur et altera pars (let the other side be heard too), or ei incumbit probatio qui dicit, non qui negat (the burden of proof is on the one who declares, not the one who denies). Most of the dicta used in legal practice refer to special topoi-loci specifici, related to our specialised legal knowledge. ${ }^{3}$ We like to use them because they are a meaningful addition to legal discourse; by supplementing our arguments, they fill the gap between general rules of argumentative discourse and the applicable regulations.

1 Ch-L de Secondat, baron de La Brède et de Montesquieu De l'esprit de lois Bk 6 Ch 15 (http:// classiques.uqac.ca/classiques/montesquieu/de_esprit_des_lois/partie_1/esprit_des_ lois_Livre_1.pdf at 105 (accessed 20 Jan 2014); trl into English by Thomas Nugent The Spirit of Laws (New York, 1899) at 87.

2 F Longchamps de Bérier “'Audiatur et altera pars.' Szkic o brakującej kolumnie Pałacu Sprawiedliwości” in W Uruszczak, P Święcicka \& A Kremer (eds) 'Leges sapere.' Studia i prace dedykowane Januszowi Sondlowi w 50 rocznice pracy naukowej (Krakow, 2008) 271-283 at 272. Cf J Stelmach \& B Brożek Sztuka negocjacji prawniczych (Warsaw, 2011) at 77-78. 
But how can we best use Latin maxims and sentences? After all, they are used by the contemporary legislator who incorporates them into legal regulations, and are invoked by judges and parties to proceedings. They are bandied about by prosecuting attorneys, solicitors, politicians and publicists in periodicals and newspapers. Here Roman law has proven to be very much alive today, becoming a more or less recognized element of the legal knowledge of contemporary societies, a permanent component of their legal culture. ${ }^{4}$

We should endeavour to use that knowledge in a competent manner, and not only on isolated occasions. As an example of how Latin dicta could be used, let us look at nemo plus iuris, a phrase that we may recall not only from Roman-law classes.

Today, nemo plus iuris is useful in legal deliberations covering a multiplicity of topics. Years ago, Krzysztof Amielańczyk demonstrated its usefulness when answering the following question:

If a share purchase agreement is concluded for shares in a limited liability company which are in fact non-existent, because they were created as a result of a legal act performed in violation of the formal provisions, thus resulting in an unlawful increase in the company's share capital, whereby the number of rights (shares) in that company did not in fact increase, can such agreement be deemed invalid in view of the nemo plus iuris rule? ${ }^{5}$

The seller did not, in fact, have the rights he claimed he had. After an in-depth analysis, Amielańczyk came up with an answer in the negative.

Nemo plus iuris may be invoked in a variety of contexts. A more recent example related to the question whether a legal person has rights if the legal persons that conferred those rights do not themselves have such rights. The Constitutional Tribunal of Poland had to decide whether a constitutional complaint could be brought by a company incorporated by entities not having such capacity, for example local government bodies, or business entities whose activities were funded out of the assets of the State Treasury or local government bodies. Such public entities perform public tasks in the spheres of both imperium and dominium. Assets are the fundamental criterion differentiating public entities from private entities.

Pursuant to Article 79 paragraph 1 of the Constitution, everyone whose constitutional freedoms or rights have been violated shall have the right to challenge the Constitutionality of the statute or another normative act on whose basis a court or public administration body has made a final decision on his freedoms or rights or on his obligations specified in the Constitution. ${ }^{6}$

$4 \quad$ H Kupiszewski Prawo rzymskie a wspótczesność 2 ed (Krakow, 2013) at 155.

$5 \quad$ K Amielańczyk "Zastosowanie rzymskiej zasady 'nemo plus iuris ad alium transferre potest quam ipse habet' do oceny skuteczności zbycia nie istniejących udziałów w spółce z ograniczoną odpowiedzialnością" in M Mozgawa, M Nazar, J Stelmasiak \& T Bojarski (eds) Materiały z konferencji 'Polska lat dziewięćdziesiatych. Przemiany państwa i prawa'. Lublin-Kazimierz, 28-30 kwietnia $1997 r$. vol 3 (Lublin, 1997) 355-362 at 356.

6 Ts 13/12 (18.12.2013, otk.trybunal.gov.pl/orzcznictwo/otk.html (accessed 28 Feb 2015). 
Can the above-mentioned company therefore be considered an entitled entity within the meaning of the term "everyone" as used by the legislator? While leaving the answer to the Polish Tribunal, which came up with a positive answer, we should add that because a matter relates to public law it does not preclude invoking nemo plus iuris. In Roman public law it was already a rule, which is particularly visible with reference to the delegation of power and its acquisition. The famous second century AD jurist, Julian, wrote in the first book of his Digest, D 2 15: More maiorum ita comparatum est, ut is demum iurisdictionem mandare possit, qui eam suo iure, non alieno beneficio habet (It has been provided by ancestral custom that a person may delegate the administration of justice to another only where he has it by his own right and not through the favour of another). By referring to mos maiorum, Julian was stressing the ancient roots of the rule that the scope of delegated power depended on the power held by the delegating party. ${ }^{7}$ In referring to the latter as having the power by right, he was emphasising the structural impossibility of delegating power that had been delegated. ${ }^{8}$

From the point of view of legal theory, nemo plus iuris is a classic example of the reconstruction of a legal rule by induction, namely by means of an analysis and generalisation of particular regulations, sometimes relating to narrowly defined legal situations. In Polish law, it is not a codified rule: "while never expressed in general terms, it is founded on an analysis of particular solutions which shape the mechanism for transferring various types of individual rights." To establish whether a rule such as one found in current legislation applies at a particular time, it is necessary to establish why it is considered legally binding. And when one resorts to such a rule and wishes to make efficient use of it, it is advisable to invoke not only dogma but also its historical development; not so much to determine whether or not it was binding, but rather how it was understood and perceived at different times in history and under various legal systems.

\section{Use maxims competently}

When determining how to make competent use of the Latin maxim beginning with the words nemo plus iuris, we should first answer the question: what precisely is nemo plus iuris - a principle, a rule, a maxim, a definition or an adage? The answer will, above all, help us to introduce the phrase itself properly, for without further clarification nemo plus iuris sounds a little awkward. Secondly, particularly when writing, we may need to find a semantically equivalent phrase, so that we do not need

7 D 11646 Ulpian On the Duties of the Proconsul Bk 1; cf D 1165 Papinian Questions Bk 1; D 11661 Ulpian On the Duties of the Proconsul Bk 1.

$8 \quad$ D 121 5pr Paul On Plautius Bk 18; D 12111 Papinian Questions Bk 1.

9 M Safjan "Zasady prawa prywatnego" in M Safjan (ed) System Prawa Prywatnego. Prawo cywilne - część ogólna vol 1 (Warsaw, 2007) 261-308 at 265-266. 
to keep repeating nemo plus iuris several times in the same sentence or paragraph. Thirdly, we need to determine the meaning of words such as "principle", "rule", "maxim", "adage", so that we know when it is appropriate to use them. For instance, Greek $\pi \alpha \rho$ o $\mu$ í $\alpha$ - paroimia, is a proverb, maxim, saw, and digression. ${ }^{10}$ But are these meanings interchangeable?

Another preliminary issue concerns the correctness of the Latin phrase and its origins. Sometimes we may have the impression that a Latin dictum we remember or have stored somewhere in the recesses of our mind may reinforce our legal argument. However, before using it we should firstly be sure of the exact wording; secondly, that we understand what it truly means or may mean; and finally, whether it is appropriate to use it in a particular context to support our argument. We must be sure of understanding the entire context and the extent to which we may rely on it to develop our line of reasoning. We certainly do not want to expose ourselves to ridicule, so we need to ensure that using certain expressions will not lead to unpleasant surprises, especially baffling ones. If our adversary is better prepared than we are, he may accuse us of superficiality, or - even worse - refute our arguments by invoking the same Latin phrase in a broader or different meaning. There is nothing worse than having your own weapon turned against you; the easiest way to silence people is to turn their own words against them.

Nemo plus iuris is only part of a maxim of which even the writings on Roman law give different versions: nemo plus iuris transferre potest, quam ipse habet; ${ }^{11}$ nemo plus iuris in alium transferre potest quam ipse habet; ${ }^{12}$ nemo plus iuris in alium transferre potest quam ipse haberet ${ }^{13}$ and nemo plus iuris ad alium transferre potest quam ipse haberet. ${ }^{14}$ The phrases differ in length; we see the forms ad alium and in alium, then habet or haberet running parallel to one another. We should therefore endeavour to find the original. Origo means the beginning, the origin, the source; we should, therefore, try to establish when this Latin phrase first appeared. To do this, we first need to look at ancient legal sources, for even if nemo plus iuris did not derive from them, we are interested in the phrase from a legal point of view and in a legal context.

Let us begin with the last and fiftieth book of Justinian's Digest, and last and seventeenth title De diversis regulis iuris antiqui. It is here that the compilers collected passages from works by Roman jurists, summarising the legal solutions adopted in ancient pre-classical and classical law. In the fifty-fourth passage, we find the memorable sentence: nemo plus iuris ad alium transferre potest, quam ipse

10 HG Liddell \& R Scott A Greek-English Lexicon 9 ed (Oxford, 1961) at 1342.

11 F Schulz Principles of Roman Law (Oxford, 1936) at 259.

12 A Stelmachowski "Nabycie i utrata własności" in T Dybowski (ed) System Prawa Prywatnego. Prawo rzeczowe vol 3 (Warsaw, 2003) 303-412 at 315.

13 Kupiszewski (n 4) at 220.

14 A Kacprzak, J Krzynówek \& W Wołodkiewicz 'Regulae iuris. ' acińskie inskrypcje na kolumnach Sąu Najwyższego Rzeczypospolitej Polskiej (Warsaw, 2001) at 117. 
haberet. So now we know it is ad alium and haberet! Justinian's commission in a prescription indicated the author of the maxim and the work from which it derives: Ulpian, Book 46 ad edictum (Commentary on the Edict). Now we are certain of our sentence's original wording, and we should keep to it. The compilers treated quotations with respect; we should definitely follow suit. So when quoting the words nemo plus iuris ad alium transferre potest, quam ipse haberet, we need to provide an appropriate footnote referring to "D" or "Dig" for the Digest of Emperor Justinian, and to passage 54 in Title 17 of Book 50, as follows: 501754 .

\section{Be aware of the context of your quotation}

The essence of Romanist training includes not only consistent quotation of original sources, but also an in-depth study of the context in which a particular thought appeared. No quotations or collections of thoughts are of any value unless we know exactly who is being quoted and the origin of the quotation. We cannot delight in a quotation if we are uncertain of the accuracy of the wording. In addition, if the source of a passage has been scrupulously recorded, it is mandatory to check the original and thus avoid the errors that may arise if we quote references "second hand." These errors more usually comprise wrong numbers than misspelt words, resulting in a variety of distortions.

We may not always be able to identify the author, the work, or even the period when a particular Latin phrase was formulated. Some dicta reflect the Roman-law doctrine or "are substantiated by the legal view as expressed by the Roman jurists". ${ }^{15}$ In such cases, even if we are unable to find a particular phrase or expression in ancient legal, or even non-legal sources, we may rely on ancient lore to authenticate our theses by saying: "The Romans used to ..." However, not all Latin dicta necessarily come from Roman law. Frequently repeated, they may occur in parallel and equally valid versions. ${ }^{16}$ The use of different words in a maxim may result from the author's personal preferences, or the stylistic requirements imposed by the context. The jurist Paul wrote on one occasion: confessus pro iudicato est (the confessed is as judged), and on another: confessus pro iudicato habetur (the confessed is held to have been judged). Justinian's compilers cited both maxims at the beginning of the same title

15 K Amielańczyk “O rzymskim pochodzeniu zasady 'nemo plus iuris...' i jej aktualności we współczesnym prawie polskim” in W Witkowski (ed) W kręgu historii $i$ wspótczesności polskiego prawa. Księga jubileuszowa dedykowana profesorowi Arturowi Korobowiczowi (Lublin, 2008) 503-517 at 503 .

16 This comes as no surprise, but should not make us negligent. At a time when our knowledge of Latin is rather superficial, we should be uncompromisingly faithful to the original wording. In ancient Rome, of course, but also in the Middle Ages and during the Renaissance or Baroque periods, it was more legitimate to attempt to formulate one's own rule or definition in Latin. 
of the Digest. ${ }^{17}$ There is no point in debating which one is correct, since the content is the same. ${ }^{18}$

Sometimes it is unclear whether a sentence that could not be traced to ancient sources appeared in the Middle Ages, or was formulated much later. Modern thoughts expressed in Latin are usually easy to recognise, and it is even easier to ascertain who authored them. Such was the case with the maxim lex retro non agit thought up by Stanisław Wróblewski. ${ }^{19}$ A more puzzling example is the old saying fiat iustitia, pereat mundus, attributed to either St Augustine or the Holy Roman Emperor Ferdinand $\mathrm{I},{ }^{20}$ or to Pope Adrian VI. ${ }^{21}$ As the embodiment of ideas held by persons fanatical about justice, it was popular in the sixteenth century. It may be translated as follows: "Let there be justice though the world perish." If mundus is understood as meaning the great of this world, the thought sounds very reasonable and timeless, expressing a rather different postulate: "Let justice be served and overcome the haughtiness and pride of the great of this world." The sentence tells us to focus on what is good and just, regardless of what the wealthy and powerful think or are demanding.

Justinian's compilers had the good habit of citing sources: "Ulpian, Book 46 of his Commentary on the Edict". Such prescriptions (placed, as the word suggests, at the beginning) before the quoted text showed their respect for the authority being quoted and hid their own thoughts behind his words. Indeed, the whole of the Digest is "written with a pair of scissors": this hefty volume came into being by combining fragments of passages, sometimes even interwoven with one another, selected from the works of pre-classical and classical Roman jurists. Like the works of classical jurisprudence in Justinian's compilation, in the post-classical codes the passages from selected imperial constitutions were also arranged thematically. When we realise that a work compiled in the sixth century AD includes materials dating from between the first century $\mathrm{BC}$ and the third century AD, whose legally binding force was thus confirmed, we should ask the serious question what did nemo plus iuris ad alium transferre potest, quam ipse haberet mean when Ulpian first used it at the beginning of the third century, and what did it mean in Justinian's time, more specifically in the Digest? This quotation is not the only one which, taken out of context, gives the impression of eloquence and timelessness. The Romans were also aware of that phenomenon. The works and style of Ulpian's peer, the jurist

17 D 4221 Paul On the Edict Bk 56; D 4223 Paul On Plautius Bk 9.

18 Cf C 7591 (Caracalla in AD 211): Confessos in iure pro iudicatis haberi placet.

19 W Wołodkiewicz, "Lex retro non agit”" in W Wołodkiewicz \& J Krzynówek (eds) Eacińskie paremie w europejskiej kulturze prawnej i orzecznictwie sądów polskich (Warsaw, 2001) 153-192 at 153.

20 C Michalunio 'Dicta. 'Zbiór lacińskich sentencji, przystów, zwrotów, powiedzeń (Krakow, 2005) at 181 .

21 According to D Liebs Lateinische Rechtsregeln und Rechtssprichwörter (München, 1998) at 84 the quotation originally comes from I diarii 33 of Marino Sanuto. 
Paul, made it very easy indeed: his phrases conveyed the meaning perfectly and succinctly. He was not particularly insightful or creative in legal terms, but some of his sentences are so succinct and clear that a separate collection has been compiled, under the telling title Pauli Sententiae. ${ }^{22}$ The maxim nemo plus iuris must have been "living a life of its own" ever since it was included in the Commentary on the Edict. However, its independent existence was ensured after Justinian's commission chose it in the sixth century AD and entered it in the Digest under a special title on the rules of ancient law.

The prescription that provides information on the origin of a particular passage - more particularly by entering the number of the book in the Commentary on the Edict-makes it easier to find the palingenetic context in which the phrase nemo plus iuris appeared in Ulpian. Palingenesis (from the Greek words: palin - again, and genesis - creation) is an attempt to reconstruct a text that has been lost. ${ }^{23}$ To judge by the passages found in thematically ordered groupings in the Digest, Otto Lenel made such an attempt in the second half of the nineteenth century. Not only did he group the texts by author and by that author's particular books, but he also suggested the order in which they may have originally appeared in each book. In the case of works discussing a number of issues, such as the many volumes of the Commentary on the Edict, passages from the works of jurists were separated according to the compilers' annotations found in the prescriptions. This made it possible to establish which issues a particular jurist discussed in a particular book. Thus, even a cursory glance at all eleven passages ${ }^{24}$ in Book 46 of Ulpian's Commentary on the Edict shows he was discussing issues related to intestate inheritance under the praetor's edict (bonorum possessio). ${ }^{25}$ This shows that the comment "no one can transfer greater rights to someone else than he himself possesses" was made in the context of the law of succession, or more precisely in that branch of the law of succession that was developing dynamically as a result of the activities of the jurisdictional magistrate. This should come as no surprise to us, because the law of succession was a driver of progress in Roman law. It avoided theoretical solutions when there was no practical need for them; however, we do find a number of theoretical solutions in the Roman law of succession, which resulted from the complexity and diversity of the issues concerned, as well as the detailed nature and comprehensive scope of the solutions adopted.

Ulpian's short commentary nemo plus iuris ad alium transferre potest, quam ipse haberet acquired a general meaning when the compilers highlighted one sentence that

22 F Longchamps de Bérier L'abuso del diritto nell'esperienza del diritto privato romano (Torino, 2013) at 149.

23 Cf, eg, M Zabłocka Ustawa XII tablic. Rekonstrukcje doby renesansu (Warsaw, 1998) at 10.

24 O Lenel Palingenesia iuris civilis 2 vols (Leipzig, 1889) vol 2 col 720-723 Ulpianus 1193-1203.

25 CfO Lenel Das 'Edictum perpetuum. 'Ein Versuch zu seiner Wiederherstellung (Leipzig, 1927) at 355-359. 
merely defined the scope of transferred rights. According to Lenel, Ulpian's comment may have referred to in iure cessio hereditatis, ${ }^{26}$ that is, cession of (relinquishing) an inheritance before a praetor. It took place before an heir accepted an intestate inheritance under civil law. ${ }^{27}$ "Since hereditas is intangible, it can be transferred only in the form of in iure cessio. The cessionary of in iure cessio hereditatis becomes a universal successor of the testator." 28 This resulted in transmitting eligibility to inherit from one living person to another, providing that while only the cedens had been eligible to inherit, the cessionary became the heir with immediate effect. ${ }^{29}$ Deliberations on the content and scope of the transferred right related to succession under ius civile, which, in the praetorian order, appeared in the second class of intestate eligibility to inheritance, called unde legitimi, probably from the first words of that part of the edict. Otto Lenel placed the passage D 501754 at the end of the section devoted to unde legitimi, that is, after two other texts concerning that class. There is no further evidence that could help identify the location of nemo plus iuris more specifically in that part of Book 46 of the Commentary on the Edict. ${ }^{30}$ Fritz Schulz went even further and suggested that Ulpian may in fact have worded the phrase a little differently: Heres non plus iuris ad alium transferre potest quam ipse haberet si hereditatem adisset (an heir may not transfer greater rights to someone else than he would himself have if he had accepted the inheritance). This phrase was reworded by the compilers who replaced the subject heres by the more general nemo, while forgetting to change the conjunctive haberet into the indicative mood - habet; after all, the original text must have had a hypothetical form, ${ }^{31}$ which the rule did not need. Henryk Kupiszewski summed it up as follows: "Ulpian wanted to say that if the heir accepted venditio hereditatis, this could not encompass anything more than he would inherit on aditio." 32

26 Lenel (n 24) vol 2 col 722 n 1.

27 G 2 35; $c f$ F Longchamps de Bérier Il fedecommesso universale nel diritto romano classico (Warsaw, 1997) at 90ff.

28 W Dajczak, T Giaro \& F Longchamps de Bérier Prawo rzymskie. U podstaw prawa prywatnego 2 ed (Warsaw, 2014) at 353.

29 G 385.

30 It is only on rare occasions that a maxim is found in its original context and then repeated elsewhere as an existing rule. One example is provided by res iudicata pro veritate accipitur (for the judgment of the court is deemed true). Cited in a longer passage D 1525 from Ulpian On the Lex Julia et Papia Bk 1, it was then recorded by Justinian's compilers as a rule of ancient law D 5017 207. Prescriptions before both passages prove the compilers were quoting from the same source. This made the job easier for the author of the palingenesis; $c f$ Lenel (n 24) vol 2 col 940 Ulpianus 1978.

31 F Schulz Classical Roman Law (Oxford, 1951) at 352. The suggestion that they forgot to change the mood of the verb is doubtful. Would the compilers, working on a passage in order to establish it as a rule, neglect to give it the finishing touches, and ignore a rather simple issue in their mental processes? Ordinary negligence in a chapter as important as D 5017 amounts to inattention or carelessness on the part of the editors, at the very least.

32 Kupiszewski (n 4) at 226. 
The context in which nemo plus iuris appeared in the law of succession is confirmed by other passages from the Commentary on the Edict. In Book 76 - D 50 17160 2, Ulpian wrote: absurdum est plus iuris habere eum, cui legatus sit fundus, quam heredem aut ipsum testatorem, si viveret, thus finding it "absurd for someone to whom an estate has been bequeathed to have a better right than the heir or the testator himself if he were still living." His contemporary, the jurist Paul, mentioned in Book 12 of his Commentary on the Edict - D 5017 120: nemo plus commodi heredi suo relinquit, quam ipse habuit, meaning "no one leaves a greater benefit to his heir than he himself had". Another regula stemming from the law of succession was quoted by the compilers in passage 175: non debeo melioris condicionis esse, quam auctor meus, a quo ius in me transit (I ought not to be in a better position than the person from whom the right passes to me). The passage we refer to today as D 50171751 comes from Paul's Book 11 of the Commentary on Plautius of which only two passages have survived. ${ }^{33}$ Otto Lenel believed the book referred to wills and legacies, and suspected that the jurist was simply discussing lex Iulia et Papia,${ }^{34}$ that is, Augustus' regulations relating to marriage. The emperor sanctioned the regulations in the law of succession by depriving the unmarried or childless of their capacitas to inherit. To sum up our deliberations on Ulpian's original context, on the basis of the cited sources it has been established beyond doubt that the rule nemo plus iuris originates from classical Roman law.

It may have been formulated by Sabinus, ${ }^{35}$ and referred to by Ulpian as an aside on in iure cessio hereditatis and mancipatio. The compilers gave the statement a universal value. The law of later times and today has assumed it was only an argument, without giving it an absolute meaning. ${ }^{36}$

The third century jurist invoked nemo plus iuris in relation to the transfer of an entire estate to another person by means of the formal and abstract act of in iure cessio hereditatis: after all, there must have been some questions about the scope of universal succession. Little wonder, therefore, that the phrase was formulated in the context of the law of succession. The nemo plus iuris rule "most likely expressed the principle that both the assets and liabilities of an estate were transferred to the acquirer of an inheritance". ${ }^{37}$ We know now that eventually it became one of the fundamental principles of property law. This means that in any derivative acquisition, the rights of the acquirer may not exceed those of the transferor. The right passes to the acquirer

33 The other is D 3085.

34 Lenel (n 24) vol 1 col 1165 Paulus 1182 n 5.

35 Ulpianus provided the disputed rule in a slightly different lexical form in D $41120 p r$, coming from his Commentary on Sabinus, which gives rise to the speculation that in the first century AD he had already formulated the idea that one cannot transfer to another more rights than he himself has.

36 Kupiszewski (n 4) at 227.

37 Kacprzak, Krzynówek \& Wołodkiewicz (n 14) at 117. 
together with all its possible limitations. In Prawo rzymskie a współczesność (Roman Law and Modernity), a book that has been a constant source of inspiration and has not lost its relevance over the past twenty-five years, Henryk Kupiszewski gave an example of how part of a statement may be subject to reinterpretation in the history of ancient Roman law as a result of legal development:

The regula talks about ius transferre. This phrase had different meanings in classical and Justinian law. Classical jurisprudence did not yet know the concept of dominium or of ius proprietatis transferre, and used the flexible term rem mancipare, rem in iure cedere, rem transferre, the res to jurists at that time meaning res incorporalis. Post-classical law used the more general terms dominium, proprietatem transferre, when the view that the ownership of an object could be transferred gradually became a fixed concept. ${ }^{38}$

And this concerns only one, though crucial, element of nemo plus iuris.

What meaning was attributed to the rule by Justinian's compilers? Firstly, it is not surprising they took it out of its original context. It is true that "the original wording does not provide grounds for assigning to it any far-fetched generalisations. The jurist does not seem to be pointing to a universal application, beyond what is to be found within the framework of the law of succession." ${ }^{39}$ Because the sentence nemo plus iuris ad alium transferre potest quam ipse haberet "expresses a rational obviousness", ${ }^{40}$ not only was it a good generalisation, but it simply attracted the attention of Justinian's commission when it was working on the chapter in which legal rules are stated. The chapter summarised the Digest. Indeed, "the obviousness of the idea expressed in Ulpian's statement is so striking that one may feel a more detailed, legal commentary would be superfluous". ${ }^{41}$ In this way, the compilers helped save the maxim itself, because had it been limited to its original, narrow context, it would have sunk into oblivion despite its apt and succinct wording. Secondly, earlier on in the same Book 50, Title 17, the compilers cited, as passage 11, an excerpt from Pomponius - a lawyer living in the mid-second century AD: Id quod nostrum est sine facto nostro ad alium transferri non potest. Passage D 501711 quoted here comes from Book 5 of the Commentary on Sabinus, comprising comments on civil law. Pomponius seems to be saying in more general terms than nemo plus iuris that what is ours cannot be transferred to another without any action on our part. The above quotation leads us to the principles of property law. In the post-classical period, a combined reading of the passages from Pomponius and Ulpian gave rise to a phrase that English jurists found more to their taste: nemo dat qui non habet (no

38 Kupiszewski (n 4) at 227 n 118.

39 Amielańczyk (n 15) at 504-505.

40 Kupiszewski (n 4) at 225.

41 Amielańczyk (n 5) at 355. 
one can give who does not have). ${ }^{42}$ Naturally, this short maxim eventually developed into a rule of common law. ${ }^{43}$

In Rome, nemo plus iuris came to be used in two senses. One was the sense in which Ulpian used it, the other, the way that Justinian's jurists understood it. It is clear that in both cases, although to a varying extent, the jurists were thinking of a law, a legal rule. At the beginning of the title containing various rules of ancient law, Justinian's compilers recorded what they considered to be a rule. In the opening paragraph D 5017 1, they cited Paul's definition from Book 16 of his Commentary on Plautius:

Regula est, quae rem quae est breviter enarrat. Non ex regula ius sumatur, sed ex iure quod est regula fiat. Per regulam igitur brevis rerum narratio traditur, et, ut ait Sabinus, quasi causae coniectio est, quae simul cum in aliquo vitiata est, perdit officium suum. (A rule is something which briefly describes what a thing is. The law may not be derived from a rule, but a rule must arise from the law as it is. By means of a rule, therefore, a brief description of things is handed down and, as Sabinus says, is, as it were, the element of a case, which loses its force as soon as it becomes in any way defective.)

The passage has been analysed in depth more than once, ${ }^{44}$ but that is not our concern now; it is enough to note the two different ways of perceiving a rule: as a criterion and as a normative standard. The above text shows that our perception of it differs from that of jurists in ancient times, since we believe an exception proves the rule. In their view, an exception disproved the rule, because a rule was not a source of law, but only a summary and description of the applicable law. It was a definition, and Javolenus' famous remark was simply a warning against the absolutisation of definitions; ${ }^{45}$ the oft quoted passage comes from Book 11 of his Letters - D 5017 202: Omnis definitio in iure civili periculosa est: parum est enim ut non subverti potest (every definition in civil law is dangerous; for it is seldom that one cannot be overturned). Justinian's compilers selected that single sentence, and included it in the regulae of ancient law in D 5017 as the tenth passage from the end of the Digest. In the light of the omnis definitio warning, even if the nemo plus iuris rule was not subject to restrictions under Roman law, its importance must at least not have been exaggerated. Moreover, apices iuris non sunt iura (extreme solutions are not laws); ${ }^{46}$ which also applies to the interpretation of the rule. Bearing in mind the

$42 C f$ Schulz (n 31) at 351-352.

$43 C f$, eg, s 21(1) of the Sale of Goods Act 1979 c 54 which only refers to the existence of that maxim.

44 The text was analyzed in detail by Kupiszewski (n 4) at 189ff, but earlier also by P Stein 'Regulae iuris. 'From Juristic Rules to Legal Maxims (Edinburgh, 1966) at 67ff; B Schmidlin Die römischen Rechtsregeln. Versuch einer Typologie (Cologne-Vienna, 1970) at $7 \mathrm{ff}$.

$45 \quad C f$ Kupiszewski (n 4) at 204.

46 Cf D 171294 Ulpian Disputations Bk 7. The translation "legal tricks are not law" has been suggested by K Burczak, A Dębiński \& M Jońca Eacińskie sentencje i powiedzenia prawnicze (Warsaw, 2007) at 13. 
above proviso, we may now summarise what was said above and state that both classical and Justinian law held firmly to nemo plus iuris as a rule. Thus we have been able to learn both the original meaning attributed to nemo plus iuris, and that in which the regula was popularised.

\section{$4 \quad$ Do not let yourself be caught by surprise}

In Roman law, the said rule was of considerable significance in yet another branch of law - the law of obligations. It appeared in deliberations concerning contracts of sale, and so we should consider a passage from Ulpian in Book 29 of his Commentary on Sabinus - D 411 20pr-1:

Traditio nihil amplius transferre debet vel potest ad eum qui accipit, quam est apud eum qui tradit. Si igitur quis dominium in fundo habuit, id tradendo transfert, si non habuit, ad eum qui accipit nihil transfert. Quotiens autem dominium transfertur, ad eum qui accipit tale transfertur, quale fuit apud eum qui tradit. (Delivery should not and cannot transfer to the transferee any greater title than resides in the transferor. Hence, if someone conveys land of which he is owner, he transfers his title; if he does not have ownership, he conveys nothing to the recipient. Now whenever ownership is transferred, it passes to the transferee to the same extent as it was held by the transferor.)

In the first of the sentences quoted above, the jurist gave a slightly different wording to the nemo plus iuris rule. The palingenetic context of the above excerpt clearly indicates that Book 29 was concerned with emptio venditio. ${ }^{47}$ Incidentally, it is worth noting that the entire fragment confirms that the preposition $a d$ was more appropriate than in when referring to the transfer of property rights - at least in Ulpian. ${ }^{48}$ The text talks of performance in terms of a contract of sale by traditio, delivery, but it is clear that originally the third-century jurist was referring to mancipatio. In classical law, land could not be alienated through traditio. ${ }^{49}$ That typical interpolation was made by Justinian's compilers. In addition, one of the passages referring to nemo plus iuris, D 5017 177pr, which they included in the rules of ancient law in the last title of their Digest, stems from discussions on contracts of sale. The entire quotation in D 5017177 was taken from Book 14 of Paul's Commentary on Plautius: Qui in ius dominiumve alterius succedit, iure eius uti debet. Nemo videtur dolo exsequi, qui ignorat causam, cur non debeat petere (Whoever succeeds to the legal position or right of property of another must accept his rights. No one is regarded as something by fraud if he is ignorant of the reason why he may not claim). According to Otto Lenel, the first sentence in that passage, designated as "pr", referred to exceptio rei

47 Lenel (n 24) vol 2 col 1122 Ulpianus 2721.

$48 C f$ ad eg in Ulpianus On Sabinus Bk 29 - D 41120 1; but in in the same jurist, eg in On the Edict Bk 9 - D 33 17pr. and D 3327 1; and rem suam in alium transferre in Gaius Diurnal Matters Bk $2-\mathrm{D} 41193$.

49 Lenel (n 24) vol 2 col 1122 nn 5-9. 
venditae ac traditae. ${ }^{50}$ The defendant used this exceptio because the thing sought had been delivered by the plaintiff in terms of a contract of sale. The beginning of Book 14 relates to matters concerning exceptiones, namely pleas.

In terms of the emptio venditio contract, the seller was bound to deliver only vacua possessio - free and unimpeded possession, into which the purchaser could enter without interference from either the vendor or, more importantly, a third party. The buyer had to continue undisturbed, so that uti frui habere possidere licere - he could freely use, derive profits, retain and possess. Thus, what the purchaser owed was not dare, that is transfer of ownership, but facere, that is making or causing undisturbed possession. ${ }^{51}$ Naturally, if goods were transferred to the buyer by way of a formal act of disposal, mancipatio or in iure cessio, then ownership passed to the buyer. This also usually happened by means of traditio - the simple delivery of ordinary things that did not belong to the special category res mancipi. Failure to transfer ownership did not give rise to actio empti - an action on purchase - on the part of the buyer. It was a different matter if someone effectively vindicated the thing purchased from the buyer by the act of evictio. As long as the emptor

retained his habere licere, the law did not give him any protection. For a modern lawyer this must sound both surprising and inequitable ... Was the Roman law 'stiff and primitive' in this regard? First of all, we have to remember ... [that in its structure] the contract of sale contained everything that was necessary to transfer ownership except [the act of delivery by] traditio (or mancipatio). Once the object was handed over (or mancipated), and provided the vendor himself had been owner, ownership passed. ${ }^{52}$

Ulpian attested to this in Book 32 of his Commentary on the Edict-D 19111 2: Et in primis ipsam rem praestare venditorem oportet, id est tradere: quae res, si quidem dominus fuit venditor, facit et emptorem dominum ... (Firstly, the seller must provide the object itself, that is, deliver it. If the seller was its owner, his act [of delivery] also makes the buyer the owner ...). The structure of the emptio venditio contract lacked nothing. "Nothing else was necessary. But if that was so, there was neither room nor necessity for postulating a special duty to make the purchaser owner. That would be the automatic consequence of traditio (or mancipatio), which, in turn, the vendor was bound to perform.." ${ }^{53}$ Granted, the buyer made the seller the owner of the money he paid, but money was a thing that was publicly available. He was not, after all, bound to deliver specific coins, but expected to pay the price with coins of which the seller then became the owner. Having said that, Reinhard Zimmermann even noted that in Roman law the sale of generic goods was unknown: every sale was a sale of specific goods because of the obligation to deliver them; and such

50 Lenel (n 24) vol 1 col 1167 Paulus 1196 n 8.

51 R Zimmermann The Law of Obligations. Roman Foundations of the Civilian Tradition (Oxford, 1996) at 278.

52 Ibid.

53 Idem at 279. 
goods could be the property of a third party. ${ }^{54}$ It is indeed hard to imagine how much economic development would be hindered if one could only sell what one owned. The author only slightly adapted the division of generic and specific things to suit his argument; he wanted to emphasise that the purchaser expected the seller to make every effort to transfer ownership. Indeed, the seller could not be forced to do the impossible, especially since impossibilium nulla obligatio est (there is no obligation to do anything which is impossible).$^{55}$ Providing all was in order, the seller made the purchaser the owner; at worst, the buyer became the owner after some time by means of usucapio, namely usucaption. As a rule, nemo plus iuris thwarted the expectation that the seller would transfer ownership whether or not he was the owner of the thing. In particular, it protected ownership of res furtivae - stolen things. We learn from the jurist Paul that when both parties knew the thing had been stolen, or when it was known only to the buyer, the obligation did not arise at all. The situation was different when the seller knew that the object of an emptio venditio was stolen, but the buyer was unaware of this. ${ }^{56}$ In the latter case, the nemo plus iuris rule did not prevent the obligation from arising. "Genetically, [the rule] is related solely to dispositive, factual acts. Its operation is as simple as its wording." ${ }^{57}$ A question that proved more important concerned the content of the obligation, since the rational condition for its validity was the ability to perform it. The performance of a contract was possible precisely because the seller was not bound to transfer ownership, but only to ensure unimpeded possession. The only snag was that the buyer could not acquire a res furtiva by usucaption, ${ }^{58}$ even if he purchased it in good faith. The buyer could bring an actio empti against a seller who knew he was selling stolen things, not because ownership of the thing had not passed (to the buyer), but on account of bad faith. However, the real problem, to which there was no simple solution, arose when neither the buyer nor the seller knew the thing had been stolen. Both parties were being honest, and someone had to suffer the consequences, because they were still bound by a contractual tie. If the buyer received the object of the sale, which a third party then took from him using eviction, it would be unreasonable to involve the seller too. Periculum est emptoris - the risk was borne by the buyer, which became an established principle of Roman law. ${ }^{59}$ In English law, a buyer who had not become the owner could resort to the warranty of title, but such a remedy was unknown in Roman law. ${ }^{60}$ If the seller was not the owner, the nemo plus iuris rule prevented him

54 Ibid.

55 D 5017185 Celsus in his Digest Bk 8.

56 D 181343 Paul On the Edict Bk 34.

57 Amielańczyk (n 5) at 359.

58 A Kacprzak Sprzedaż rzeczy kradzionej, (2002) 2(1) Zeszyty Prawnicze UKSW 93-104 at 94-95, 102.

59 Dajczak, Giaro \& Longchamps de Bérier (n 28) at 506-507.

60 R Powell "Eviction in Roman and English law" in D Daube (ed) Studies in the Roman Law of Sale Dedicated to the Memory of Francis de Zulueta (Oxford, 1959) 78-90 at 87-90. 
from transferring ownership. Although the contract was valid, transfer of ownership was objectively impossible. Roman law only knew an implied warranty of peaceable possession. ${ }^{61}$ The thing was transferred to the buyer, and he could enjoy it as long as the owner of the thing sold did not resort to eviction and take it away from the buyer. To summarise the foregoing, we should observe that the Roman-law doctrine was adopted by the ius commune: the seller was bound to ensure vacua possessio, but was not obliged to make the buyer the owner of the thing sold. ${ }^{62}$

\section{Make sure the maxim is established in the law}

In the last title of the Digest De diversis regulis iuris antiqui, Justinian's compilers included as many as six passages confirming that it was impossible for anyone to transfer more rights to another person than he had himself. These are - in the sequence in which they were referred to above - texts from D 50 17: D 5017 54; D 5017160 2; D 5017 120; D 5017175 1; D 5017 11; and D 5017 177pr. The number of rules of ancient law to which the compilers referred shows they believed nemo plus iuris was a well-established principle of the overall legal order. And because it was a regula (a rule), in accordance with the definition provided in D 5017 1, there were no exceptions to it. Thus Roman law fully respected the nemo plus iuris rule..$^{63}$

Exceptions to that rule with regard to derivative acquisition of ownership were only apparent. The academic discussion in Gaius' Institutes, G 2 62-64, cannot be taken seriously. The jurist compared the example of an owner who did not have the authority to alienate his property with that of a non-owner who could dispose of another person's property. A husband who owned land that was part of the dowry was prohibited from transferring it in terms of the special lex Iulia de fundo dotali. The statutory limitation of an owner's rights does not require any comment. However, if a non-owner was an agnate who, under the Law of the Twelve Tables, had guardianship over a furiosus, he could alienate the latter's property; and so could a procurator of his estate. The correlation between agnatio and ownership in ancient law seems to preclude the existence of a real anomaly here. In addition, a pledge creditor could dispose of the pledged thing although he was not even the possessor of the thing, only a detentor, namely a holder. His right to alienate resulted from the pactum de vendendo - an informal agreement concerning the case in which a debt secured by a pledge is not repaid. And one can only agree that it is a paradox that uti frui ius sibi esse solus potest intendere, qui habet usum fructum, dominus

61 Zimmermann (n 51) at 293-294.

62 Idem at 303.

63 Unlike Kupiszewski (n 4) at 225, who wrote: "On close examination it soon turns out that today and in classical or Justinian Roman law it never had an absolute value. For it is neither always true that a right cannot be transferred by a non-owner, nor that it can be transferred by the person who is." Legal intuition correctly takes into account the need for compromise. The examples he provided referring to Roman law in his substantiation are those we consider apparent exceptions. 
autem fundi non potest (the only person who can claim by law that he has the right to use and enjoy property is the man who has the usufruct of it). The rule was stated by Ulpian in Book 17 of his Commentary on the Edict - D 76 5, and followed by the explanation: quia qui habet proprietatem, utendi fruendi ius separatum non habet: nec enim potest ei suus fundus servire (the owner of the property cannot do so, because a man who has ownership does not have a separate right of use and enjoyment; the fact is that a man's estate cannot be subject to a servitude in his own favour). In Book 65, the jurist referred to a similarly academic way of reasoning D 41 146: non est novum, ut qui dominium non habeat, alii dominium praebeat: nam et creditor pignus vendendo causam dominii praestat, quam ipse non habuit (it is no novelty that one who does not have ownership may still confer ownership upon another; a creditor, for instance, in selling a pledge, gives title to ownership that he does not have himself). We should also add that Paul, in his characteristically concise manner, wrote in a single book On Exceptional Law - D 71 63: quod nostrum non est, transferemus ad alios: veluti is qui fundum habet, quamquam usum fructum non habeat, tamen usum fructum cedere potest (we can transfer to others what we do not ourselves have; for example, if a man has an estate, then even although he does not hold the usufruct, he can still grant usufruct to another). The nemo plus iuris rule reverberates in this quotation in the phrase quod nostrum non est and the verb transferemus. Ususfructus is not ownership, and an owner does not actually have usufruct - in the sense that we cannot say he only has a limited right, since the owner's right to the thing is much broader than the right to usufruct. Therefore, formally, the owner establishes something that did not exist before - he isolates from his property the right of ususfructus, but does not transfer to another person a right to which he himself would not be entitled. The content of the right of usufruct is contained within the right of ownership. Therefore the conclusion that we can transfer to another what is not our own is a play on words and constructions, an uncomplicated brainteaser and without any substantive value. Legal issues can be constructed or stated in a way that suggest we are dealing with exceptions while in reality there is no exception here at all.

\section{Do not neglect related and supporting maxims}

The protection of ownership in Roman law went even further than set out above, finding its place in the broader context of securing control over a thing. Hence the counterpart to nemo plus iuris in respect of actual control - in the form of nemo sibi ipsum. Paul stated in Book 54 of his Commentary on the Edict-D 4123 19: illud quoque a veteribus praeceptum est neminem sibi ipsum causam possessionis mutare posse (the earliest jurists further laid down that no one can change for himself the title by which he possesses something). When stating the rule, the jurist also invoked the earliest jurists so that we would know how long it had formed part of the law. 
The question of its relevance or validity is another matter. We can say a rule is true if it only describes the law of a particular time and its role is then largely one of interpretation. If compliance with a rule is sought, the basis of its current validity should be specified. Legal bases may change, but even when replaced by new ones, they may express an unchanging rule. Thus Roman law, especially by blocking access to usucapio pro herede, prevented detentores from arbitrarily and covertly becoming rightful possessors. Nemo sibi ipsum as the counterpart to nemo plus iuris in the protection of possession represented a "systemic block" to changes in control. It protected the possessor and the owner, because strengthening possessory protection helped strengthen ownership.

The rule of nemo sibi ipsum was well established and documented in classical Roman law. ${ }^{64}$ It was adopted unreservedly by codes of natural law (Arts 2231 and 2240 CC, $\S 319$ ABGB), and the Italian civil code of 1942 (Art 1141 CCI), but rejected by the German and Swiss codes. Polish law, unfortunately, followed their example ${ }^{65}$ and adopted a purely factual concept of possession. The Supreme Court of Poland confirmed the rejection of nemo sibi ipsum when it allowed, expressis verbis, a change in the title of possession by the possessor himself. ${ }^{66}$ This, of course, does not apply to the rule that "no one can transfer greater rights to another person than he himself possesses".

\section{$7 \quad$ Take the local context into account}

Polish law respects nemo plus iuris as a rule in the sense that it perceives it as the Latin wording of the requirement that the seller be the owner or person entitled to dispose of the thing. According to Andrzej Stelmachowski, the rule has not been embodied in any Polish statute because it is obvious. The right of the owner arises from his right to dispose of the thing he owns, and specific legal relationships provide the basis for disposing of the right to ownership of another person. Moreover, the provisions of family law allow spouses to dispose of their joint marital property. ${ }^{67}$ From the perspective of Roman law, it is pleasing to note that "in Polish law, the presence of that rule is most conspicuous in the law of succession". ${ }^{68}$ It is usually perceived as the foundation of legal transactions in the derivative transfer of ownership. ${ }^{69}$ Laws have

64 D 413331 and D 41521 Julian The Digest Bk 44; D 412191 Marcellus The Digest Bk 17; D 41 23 19-20 Paul On the Edict Bk 54.

65 F Zoll \& A Szpunar Prawo cywilne $w$ zarysie vol 2 (Krakow, 1947) at 306; Stelmachowski (n 12) at 384; J Gołaczyński "Posiadanie" in E Gniewek (ed) System Prawa Prywatnego. Prawo rzeczowe vol 4 (Warsaw, 2005) 1-66 at 14-15.

66 I CR 167/59 (12.05.1959, Orzecznictwo Sąu Najwyższego 1961, item 8); SN of 12.3.1971, III CRN 516/70 (12.03.1971, Orzecznictwo Sądów Polskich i Komisji Arbitrażowych 1971, 11).

67 Stelmachowski (n 12) at 315.

68 Amielańczyk (n 15) at 512.

69 Stelmachowski (n 12) at 336. 
created exceptions to this rule, allowing the acquisition of ownership of movable property and even real property from an unauthorised person. These laws were introduced because of the need to compromise in the interests of the reliability of business transactions and respect for good faith. However, a legislative compromise between nemo plus iuris and the rival principle of protecting the interests of persons acting in good faith "affects the acquisition of the ownership of real property to a much lesser extent than the acquisition of ownership of movable things". ${ }^{70}$ In the former case, nemo plus iuris has been waived in order to reinforce confidence in the entry in a land and mortgage register, as the basis of the purchaser's good faith. ${ }^{71}$ Usucaption in bad faith is possible in Polish law only in respect of real property, and only after the elapse of thirty years of possession (Art $172 \S 2$ of the Polish Civil Code). On the other hand, the purchaser of a movable thing who acquires it from a non-entitled person becomes its owner upon taking hold of it, unless he was acting in bad faith (Art $169 \S 1$ of the Polish Civil Code). When a thing has been mislaid, stolen, or otherwise lost by the owner, a purchaser in good faith may acquire ownership after the elapse of thirty years from the time it was mislaid, stolen, or lost ( $(2)$. The rule of nemo plus iuris is therefore honoured in Polish law; and so the reliability of business transactions and the interests of the purchaser who acquires a thing in good faith from a person who is not the owner counterbalance the protection of ownership. ${ }^{72}$ The Polish legal system is based on the protection of ownership as the basis of private law, but the example of nemo plus iuris clearly shows that the law should be viewed from the perspective of the values and principles reflected in particular regulations. ${ }^{73}$ The rules of construction or interpretation result from legal policy and depend on the objectives, which here are the implemented values.

It is not only in Roman law that the protection of ownership was a general principle, fully applicable to derivative acquisition. Nemo plus iuris prevented acquisition from a non-owner: the vendor was either the owner - D 501711 , or an authorised person or the owner's representative - G 2 62-64. In such a case, ownership passed to the purchaser immediately and not by usucaption. Because the law had to protect ownership, formal acts were required for the transfer of the most valuable things, namely res mancipi. The formal, abstract acts of mancipatio and in iure cessio caused the owner to consider the transaction carefully. The same applies to the requirement of iusta causa traditionis, if a person wanted to transfer

$70 \quad$ Idem at 337.

71 Idem at 339; Amielańczyk (n 15) at 516.

72 Cf W Kowalski “Nabycie własności rzeczy ruchomej 'a non domino’ w prawie rzymskim i współczesne zmagania z problemem” in F Longchamps de Bérier, R Sarkowicz \& M Szpunar (eds) 'Consul est iuris et patriae defensor.' Księga pamiątkowa dedykowana doktorowi Andrzejowi Kremerowi (Warsaw, 2012) 77-103 at 85, 93.

73 Cf M Kordela "Stanowienie zasad prawa” in A Dębiński, P Sitarz, T Barankiewicz, J Potrzeszcz, W Staszewski, A Szarek-Zwijacz \& M Wójcik (eds) 'Abiit, non obiit.' Księga poświęcona pamięci ks. prof. Antoniego Kościa SVD (Lublin, 2013) 191-199 at 198. 
ownership by simple delivery. Further protection was provided by limiting usucapio, thus making it rather difficult in practice to acquire ownership of real property through long-term possession. Similarly, if a thing was abandoned, loss of ownership of it was not at all obvious, and certainly far from automatic. It all depended on the owner's will and the claims he made regarding the thing, even a long time after it had been abandoned. This systemic protection of the owner included the nemo plus iuris rule, which was at least one legal expression of such protection. In Roman law, ownership was clearly related to and correlated with social perceptions of it. Here we are touching upon the foundations of law. Roman-law regulation of ownership was not as stringent as many people in the nineteenth century claimed..$^{74}$ Ownership was nevertheless much more heavily protected than it is today, when the law places equal emphasis on protecting the certainty of business transactions and ownership.

\section{Conclusion}

Let us now summarise what has been established thus far. A legal dictum formulated in Latin is referred to as a rule, maxim, definition, precept, or principle. It is impossible to differentiate these terms clearly, although this has been done, for instance, in the terminology used in contracts in continental private law. Henryk Kupiszewski ${ }^{75}$ attempted to identify a fundamental difference between a maxim and a rule in Roman law - but without any success. We can certainly use equivalent terms: sentence, statement, phrase, as well as dictum. In the above discussion, the word "rule" has been used with reference to nemo plus iuris, because to Justinian's compilers, nemo plus iuris ad alium transferre potest, quam ipse haberet was a regula, as it was in the title of D 50 17. Furthermore, some writers have concluded that in certain legal contexts nemo plus iuris was and still is perceived as a rule. We should therefore decide and clearly state, on a case-by-case basis, what we understand by the terms maxim, rule, or precept at a particular time and in a particular context. For jurists, such Latin phrases and statements refer to rules that are an important tool in interpreting and applying the law. Given the role of Roman private law in the historical formation of the European legal tradition and its contemporary influence and development, its main importance lies in its fundamental rules of private law. Therefore, when considering which dicta to use in argument, we should not make do with free association, or uncritically trust our intuition. We should acquaint ourselves with the full phrase as well as the context in which it is known and how it has been used up until now. Only then can we be creative, find other ways of applying it and construct new meanings for it. It is usually pointless to ask what the author meant by it; what he had in mind may be entirely beyond our reach. Once a maxim is formulated, it takes on a life of its own, whether we like it or not. Audiences and

74 Longchamps de Bérier (n 22) at 181-185.

75 Kupiszewski (n 4) at 155-240. 
readers of various epochs or even cultures understand it subjectively. They are free to use ancient and contemporary dicta as useful tools in interpreting and applying the law. To be effective, however, they need to make an effort and be prepared and competent not only in dogmatic, but in historical terms as well.

\section{Abstract}

Lawyers use words with great care and, particularly in public discourse, often like to use Latin dicta. They do so not only to make their arguments sound more sophisticated, but also to support their theses not merely with elegantly worded, classical maxims, but also with well tested, established concepts based on the experience of people who lived in ancient Rome, a consummately practical society, very well versed in the practice of law.

A legal dictum formulated in Latin is referred to as a rule, maxim, definition, precept, or principle. It is impossible to differentiate these terms clearly, although this has been done for instance in the terminology used in contracts in continental private law.

How can contemporary lawyers best use Latin maxims and sentences? This is explored by using the example of nemo plus iuris ad alium transferre potest, quam ipse haberet. The six steps are as follows: use maxims competently; be aware of the context of your quotation; do not allow yourself to be taken by surprise; make sure the maxim is well established in the law; do not neglect related and supporting maxims; and take the local context into account. 